\title{
Household Periodicals, Modernisation and Women's Emancipation in Bulgaria (1890s to WWI)
}

\author{
Valentina Mitkova ${ }^{1 *}$
}

Published: September 8, 2020

\begin{abstract}
The aim of this article is to trace how popular publications aimed at female audiences, the women's press, contributed to the emancipation and cultural modernisation of Bulgarian women from the end of nineteenth century until 1914. The subject of research are the so-called 'household periodicals' - the newspapers and magazines addressing women, that deliberately avoided politicisation and tried to modernise and emancipate their readers within the private space of the 'women's world' (understood as home and family). Incorporating relational feminist arguments in their rhetoric, such periodicals did not confine themselves to the attempt of building an exemplary reconstruction of the private sphere in the variety of the aesthetic and moral dimensions of that field. They became a key element of the country's popular culture and had a longlasting political and social effect. An example of the household periodicals' modernising efforts and sensitivity to modern emancipatory ideas was one of the pioneering women's projects in this category, the magazine Moda i domakinstvo ('Fashion and Household'), 1897-1906, edited and published by Elena Usheva.
\end{abstract}

Keywords: women's press, household periodicals, women's emancipation, cultural modernisation

\section{INTRODUCTION}

The aim of this article is to trace how the women's press contributed to the emancipation and cultural modernisation of Bulgarian women from the end of nineteenth century until the beginning of World War I. The research focuses on the so-called 'household periodicals' - the newspapers and magazines with a targeted female readership, which deliberately avoided politicisation and tried to modernise and emancipate their readers within the 'private sphere' of the 'women's world' (understood as home and family). Analysing one of the pioneering women's projects in this category, the magazine Moda i domakinstvo ('Fashion and Household'), 1897-1906, edited and published by Elena Usheva, the article shows that the role of such periodicals did not remain confined to the exemplary reimagining of the women's world as defined above. The publication's educational and modernising efforts, channelled through editorial policy and mission, actually brought Moda $i$ domakinstvo close to the rhetoric of the 'relational' feminism typology introduced by American historian Karen Offen (Offen, 2000). ${ }^{1}$ Becoming an important part of the country's popular culture, household periodicals had an unexpected subversive effect, both socially and politically: although traditionally located in the domestic arena, they actually contributed to intensifying the processes of personal and social awareness of the 'second sex' (De Beauvoir, 2010) in Bulgaria, making women publicly visible and helping them to imagine themselves as active participants in building the modern (European) profile of the country. Eventually they contributed to the political mobilisation of women, supporting the cause of the explicitly feminist journals for changing public attitudes to the so-called 'woman question'.

${ }^{1}$ According to Offen (2000), by going beyond the traditional (folklore, Christian) image of women, 'relational' feminism seeks to 'rehabilitate women' and equalise the social authority of genders without challenging or diminishing the differences between them; 'individualist' feminism, by contrast, neglects gender differences and focuses on the equal intellectual capacity of women and men, as well as on personal autonomy. 


\section{THEORETICAL SCOPE AND THE STATE OF THE ART}

Research on women's periodicals in the context of modernity and modernism has been actively developed in the English-speaking world since the 1990s (Felsi, 1995; Marek, 1995; Morrisson, 2001; Ardis et al., 2003; Scott, 2007; Delap, 2007; Ardis et al., 2008; Scholes et al., 2010; Bucur, 2017). Operating in the paradigm of deconstruction and post-modernism, studies in the field have paid attention mostly to the writing, as well as intellectual and social activities, of women authors, journalists and editors who long remained at the periphery of public and academic attention, marginalised in dominant historical and cultural narratives. Such attention has deepened the understanding of the relationship between modernisation processes and gender: the emancipating role of women's magazines and newspapers as a platform for intellectual, social and political debates, opening a friendly space for self-expression and articulating new socio-cultural roles of women - as activists, producers of culture, managers of households, etc., has been internationally discussed.

Interest in the women's press with a household profile as a channel of modernisation has increased in a global context as well. Among the researchers who have studied this type of publication is Barbara Korte, who analysed the contribution of women's magazines to mid-Victorian historical culture by negotiating the social position of women as well as models of femininity (Korte, 2015). Heidi Brevik-Zender, in turn, focused on the relation between fashion and nineteenth-century French modernity through close examination of the gendered constructions of space created in mass-circulating fashion plates, which were published in women's periodicals from the second half of the 1880s (Brevik-Zender, 2014). This line has been followed by Marianne Van Remoortel, who studied the rise of the illustrated women's and family magazines in Europe and the United States in the second half of the nineteenth century. Targeting women as consumers and practitioners of style and granting them a new sense of control over their public identities, those periodicals were associated with a key moment in women's history (Van Remoortel, 2017).

In recent years the women's press has seen intensive scholarly attention as a topic of research by Southeast European scholars as well. In Serbia, historians at the Institute of Literature and Arts in Belgrade have started to include it as a part of the Institute's broader project dealing with periodicals. Another project - Knjizenstvo, Theory and History of Women's Writing in Serbia until 1915 (http:/ / www.knjizenstvo.rs) - was developed by Biljana Dojčinović at the Faculty of Philology, University of Belgrade, who in 2011 brought together the efforts of local researchers under this larger umbrella (Barać, 2015; Kolarić, 2017; Dojčinović et al., 2018). Greek women's periodicals have been the focus of the activity of a special research group at the Department of Philosophy and Social Studies, University of Crete in Rethymno, Greece, under the leadership of Katerina Dalakoura. It has resulted in the construction of a rich database devoted to the women's press (http:/ / kypseli.fks.uoc.gr/), publications (Dalakoura, 2012), thematic events, academic forums and collaborations. ${ }^{2}$

Bulgarian researchers have similarly demonstrated interest in gender issues and gendered productivity of knowledge, as well as an active preoccupation with the role of women writers in the formation of modern Bulgaria. Their focus have been mainly directed at the field of literature where, motivated by the obvious underrepresentation of women authors' works in the contents of Bulgarian textbooks and school programs, they have challenged the conservative, androcentric theoretical and historical foundations of the operating literary canon (Daskalova, 1998; 2001; Malinova, 1999; Nikolchina, 2002; Gigova, 2008: 91-119; Kirova, 2009, 2013; Kourtasheva, 2012).

While literature has attracted attention as a field with the highest level of representativeness and interplay of complex power relations, including gender hierarchies, other fields of active women's authorship and intellectual activity, like women's periodicals, are still insufficiently analysed. Among the few Bulgarian scholars who have referred to this issue in the context of more general research are Krassimira Daskalova, focusing on the first newspapers with an openly feminist discourse - Zhenskii sviat ('Women's World'; 1893-1898), and Zhenski glas ('Women's Voice'; 1899-1944) (Daskalova, 2012), and Georgeta Nazurska, analysing the cultural reception of Bulgarian women's periodicals from the 1930s and the 1960s, based on a private archive (Nazurska, 2007). Other researchers who have paid attention to women's press in the country within the context of the series Periodika $i$ literatura ('Periodicals and Literature') - a general literary study and description of the periodical press in Bulgaria from 1878 to 1944, are Leonita Dorosieva, analysing the women's journal Moda i domakinstvo ('Fashion and Household'; 1897-1906) (Dorosieva, 1993), and Lyudmila Malinova, focusing on the newspaper Grazhdanka (Woman Citizen; 1911-1912) (Malinova, 1995).

\footnotetext{
${ }^{2}$ In November 2018, the Department of Philosophy and Social Studies of the University of Crete, in collaboration with the Hellenic Open University's Master's Program in Public History, under the auspices of the Regional Unit of Rethymno, organised an exhibition and conference entitled 'Women's Press - Women in the Press'; see http://ottomanwomenspress.fks.uoc.gr/ (Accessed on 25 April 2020); Katerina Dalakoura has also actively contributed to the permanent section related to women's press of the Women's Museum Istanbul online exhibition; see http://www.istanbulkadinmuzesi.org/en/efrosini-samarcidis/?tur=Tematik (Accessed on 18 May 2020).
} 
Despite the in-depth analyses of a few representative projects, the Bulgarian women's press still awaits comprehensive research as a field of construction and reconstruction of women's collective identities and activities, a forum for debating the 'woman question' and understanding public interventions. Its function as a place of advancing women's writing and reading, communication and power network development, a platform for negotiation of modern (bourgeois) styles of life should be further analysed, as well. Last but not least, women's periodicals need to be studied as an entrepreneurial activity - a step towards the exit of cultivated and increasingly educated women out of the private environment and into the challenging public sphere.

\section{THE WOMEN'S PRESS WITHIN THE CONTEXT OF BULGARIAN MODERNISATION}

The attention to the so-called 'woman question', or the emergence of the public interest in women's gender roles and needs (the basis for the appearance of women's periodicals), was born in the Bulgarian context due to the promotion of emancipatory ideas and trends in a gradually changing patriarchal society. The first were registered in the middle of the nineteenth century, during the period of the so-called Bulgarian national revival, within the Ottoman Empire. Emancipatory ideas and trends were mostly conceived as innovations in mentality and behaviour, social habits, gender communication and the perceptions of women and their situation in society. Those tendencies intensified after the creation of the nation state in 1878 . They denoted the gradual transformation of Bulgarian culture, from a focus limited to its own social order and value system, to an externally-focused approach, open to foreign influences and aimed at following and assimilating European experience.

In the context of Bulgaria's predominantly peasant society, with a tiny middle class, it is not surprising that the first feminists who insisted on equal, including political, rights were small in number. Starting from the middle of the nineteenth century, but mostly in the 1860s and 1870s, a kind of literary feminism developed on the pages of the Bulgarian periodicals that advocated for women's need for education and 'progress' (Daskalova, 2012). With the exception of a few women authors and translators, this literary feminism came mostly from male representatives of the intelligentsia, as only a fraction of Bulgarian women were literate, and still fewer had access to print media. Similarly to their counterparts in other European countries and especially in France, most male intellectuals insisted that women should be educated. But they used traditionalist arguments to support a normative view of femininity, aiming to enhance the role of women as mothers, wives, and educators of future Bulgarian citizens and patriots. Following that line, the ethos of the first magazine addressing women, edited by the male journalist, author, and national activist Petko R. Slaveykov in Constantinople in 1871, Ru₹bitsa ili red knizhki za zhenite ('Ruzhitsa or a number of booklets for women'), was essentialist, sharing the belief in the existence of specifically female, biologically rooted predispositions (Daskalova, 2001).

The establishment of the Bulgarian nation state in $1878^{3}$ brought changes in infrastructure and accelerated efforts to modernise the urban physical environment. The mentality and normative culture of Bulgarian society changed slowly, however. As in the other Balkan recently established states (Greece, Romania, Serbia, Albania, and eventually Turkey), as well as elsewhere in Europe, Bulgarian women were deprived of a number of the rights and privileges provided to male citizens in the fields of education, professional life, and political participation (Daskalova, 2012: 289-343). Modern feminism in Bulgaria was born in response to the exclusion of women from full participation in public life and deprivation of full benefits as citizens of the nation state.

Europeanisation trends were further accelerated by the growing number of periodicals as a form of modern public interaction. The Bulgarian women's press can be studied as an independent category of this expansion of the public sphere, namely within a modernising context marked by the development of print culture, the rise of literacy, and the growth of a broader reading public that fostered more pluralistic writing, as well as contestation of certain realities affecting women. As Amelia Sanz and Susan van Dijk observed for a different context, the appearance and proliferation of women's periodicals in Bulgaria demonstrated that, despite limited citizenship rights, women were neither fully excluded from nationhood and modernisation of the state, nor did they exclude themselves from that process (Sanz et al., 2014: 18). More than that, the transformations of the twentieth century, that gradually affected Bulgarian developments, as Maria Bucur shows for another context,

can be fully grasped only by analyzing how women have been both the subject and object of these major shifts, from an unprecedented set of new rights to new cultural norms, and overall greater agency as a category of humans (Bucur, 2018: 4).

\footnotetext{
3 The restoration of Bulgaria was confirmed by the Treaty of Berlin from 1878. However, legally until 1908, the newly established Bulgarian state was dependent on the Ottoman Empire, as a nominal vassal and tributary principality with its own national government and troops. The Eastern Rumelia region remained in the Ottoman Empire but enjoyed administrative autonomy, including its own armed forces. The two Bulgarian regions were officially united in 1885. Bulgaria declared its independence as a sovereign state in 1908 , when the necessary conditions for this were created.
}

(C) 2020 by Author/s 
That involvement was channelled by a subcategory of women - educated, urban, usually from the higher strata of society, who directed their energy and efforts toward intellectual and social activism.

The development and increase in the number of women's newspapers and magazines in Bulgaria is mainly associated with the names of the first women professionally engaged in editorial and publishing activities, sensitive about the different exclusions and discrimination of women in the free nation state in the fields of education, access to various, social and political rights. The titles of these periodicals advertised specific views of the 'woman question'. Periodicals like Zhenskii sviat ('Women's World'; 1893-1898), edited by Teodora Noeva, Semeino ognishte ('Family Hearth'; 1895), edited by Maria Nedyalkova-Popova, Bulgarka. Mesechno semeino spisanie ('Bulgarian Woman: Monthly Home Magazine'; 1896-1904), edited by Alice P. Kurshovska, and Moda i domakinstvo: Semeen z̧hurnal ('Fashion and Household: Family Journal'; 1897-1906), edited and published by Elena Usheva, made efforts to raise women's self-awareness and public visibility starting from their traditional sphere of activities - the private space of home and family. The organ of the Bulgarski Zhenski Sujuz (Bulgarian Women's Union), the newspaper Zhenski glas ('Women's Voice'; 1899/1901-1944), as well as the newspapers Ravnopravie (Equality, 1908-1921), Zhenski vestnik ('Women's Newspaper', 1918), and Bulgarka ('Bulgarian Woman'; 1918), edited by Anna Karima and Graz̧bdanka ('Woman Citizen'; 1911), edited by Zheni Bozhilova-Pateva focused on women's rights as citizens, equality with men, while addressing important topics related to women's professional and social realisation. Newspapers and magazines like Ikonomia i domakinstvo ('Economy and Household'; 1921-1944), and Zhenski vestnik. Nezavisim obshtestven sedmichen vestnik za informacia, literature i domakinstvo ('Women's World': independent public weekly newspaper for information, literature and the household; 1928-1930), edited by Teodora and Stefan Peikovi, Vestnik na zhenata ('Woman's Newspaper'; 1921-1944), edited by Penka and Hristo Cholchevi, Zhensko ogledalo. Sedmichen ijustrovan vestnik za domakinstvo, moda, izkustvo, literatura $i$ zanimatelno chetivo za zhenata ('Woman's Mirror: weekly illustrated newspaper for the household, fashion, art, literature and entertaining reading for the woman'; 1923-1926), edited by L. I. Dilberova, as well as Moderna domakinia ('Modern Housewife; 1924 - 1942), edited by Anastasia Miteva, aimed at building a modern profile of Bulgarian women not only by trying to increase their practical knowledge of household maintenance, but also by expanding their horizons, cultivating reading habits, provoking curiosity about a modern lifestyle, and so on. Periodicals like Zhenski glas (1926-1944) and Zhenata ('The Woman'; 1928-1930), edited by Dimitrana Ivanova, Vestnik na zhenata ('Woman's Newspaper') and Zhena i dom ('Woman and Home'; 1937-1944), edited by Nella Slivopolska, Beseda/Dom i sviat ('Conversation/Home and World' (1934 - 1943), edited by Elisaveta Konsulova-Vazova, in turn oscillated between the public and private spheres, addressing women and their needs.

According to their guiding principles and editorial policies, women's periodicals in modern Bulgaria can be separated into two basic groups: journals with a clearly stated 'individualist' feminist discourse, in terms of Offen's definition (2000), and women's magazines and newspapers that deliberately avoided open politicisation. The first, mostly led by women associated with Bulgarian women's organisations, highlighted the specific gendered aspects of women's experiences by focusing on topical socio-political issues that corresponded to the situation of 'the second sex' in Bulgaria. The journal Zhenskii sviat and the newspaper Zhenski glas were among the most influential. Zhenskii sviat was the first Bulgarian periodical to systematically present the major developments in the struggles for women's emancipation, revealing the meaning of the term 'feminism' and connecting it to the local Bulgarian and Balkan contexts. Its ideological heirs, the publications Zhenski glas, Graz̧bdanka and Ravnopravie, articulated the highest degree of sensitivity in terms of women and their rights, social status and capacities for self-realisation beyond the traditional modes of existence. Those periodicals interpreted national modernisation through giving women a broader choice of life and making them significant actors on the political, social and cultural scene of the country.

The second group of periodicals, such as Moda i domakinstvo, Ikonomia i domakinstvo, Vestnik na zhenata, Moderna domakinia, Zhena i dom, strove to modernise (Europeanise and Westernise) their readers within the 'women's world', understood as the private sphere of home and family. Their ambition to inform, enlighten, and shape cultural attitudes among Bulgarian women was usually paralleled by the implementation of educational and utilitarian goals such as improving morality, habits of household maintenance, health and pedagogical culture, tastes for literature and fashion (Nazurska, 2007). These new attitudes were recognised as a necessity in the course of Bulgarian modernisation from the end of the nineteenth and the beginning of the twentieth century, paralleled by the growing urbanisation and popularisation of European modes of life in their secular and public aspects (Daskalov, 2015; Katsarov, 1970; Georgiev, 1970). Hence the profile of the readership of household periodicals: they were predominantly urban women, educated, and with habits of consumption reflected in the periodical press; as teachers, students and housewives, possessing a well-defined 'modern' potential, these women were urged to depart from the simple upholding of tradition and instead to seek new directions for personal development.

Covering a large range of topics, the household periodicals in Bulgaria dated back to the end of the nineteenth century and kept their profile until the 1940s, when the communists took over. As Georgeta Nazurska has pointed out, this category included forty-four titles: 23 per cent had a practical and literary focus, 60 per cent were edited 
only by women or by women in cooperation with men, and 95 per cent were addressed to the whole family (Nazurska, 2007: 11).

Only one influential magazine with a similar profile was published before World War I, Moda i domakinstvo, while the highest frequency of household periodicals with diverse content (culinary and fashion tips, but also literary works and articles on health, etiquette, social life, etc.) was registered in the interwar period (Nazurska, 2007: 11). By creating an alternative public space in which women were actively involved as authors and readers, household periodicals, and the women's press in general, as an economic, political, and cultural entity, played the role of a social mechanism transforming women's identities and playing a key role in women's engagement with the creation of a new, more gender-inclusive citizenship (Vujnović, 2008: 15; Vujnović, 2009).

\section{ZHENSKII SVIAT, 1893-1898}

The prototype of the specialised women's press in Bulgaria was a syncretic form of women's newspaper published in Varna between January 1893 and December 1898 by educator and activist Teodora Noeva. Zhenskii sviat ('Women's World') was the first to draw readers' attention to the fact that the Constitution (1879) did not treat women and men as equal citizens. During its six years of publication, the periodical appeared in twenty-four issues annually. It had a supplement, entitled Domakinia ('Housewife'), which was edited by Elena Manova, Noeva's younger sister, and focused on women's roles as mothers and housewives.

The articles published in the journal included both original submissions, and translations, mostly from French and Russian. They discussed different topics, such as: the 'woman question' and 'feminism'; women's position in the society and family around the world; women's rights and duties; and women in science and art. For the first time in Bulgarian journalism, Noeva tried to systematically present the major developments in the struggles for women's emancipation around the world, to show the entanglements in the aims and strategies of women's actions, to define the meaning of the term 'feminism', and to connect it to Bulgarian and Balkan contexts.

Against the background of the ideas about women's educational, professional, political emancipation and equality with men that the magazine had long been promoting among its readers, the editor finally acknowledged that the most logical feminism for Bulgarian women was the one that counted on women's 'God-given' and 'natural' destination: childbearing and family life. That blending of individualist feminist ideas with relational feminist arguments, however, was quite logical in the nineteenth-century Bulgarian context, with its predominantly peasant population, tiny middle class and lack of opportunities for professional work of educated women (Daskalova, 2016: 10). Articulation of relational feminist ideas was also representative for many household periodicals in early modern Bulgaria, and especially for one of the pioneers in that category - the magazine Moda $i$ domakinstvo.

\section{MODA I DOMAKINSTVO, 1897-1906}

Moda $i$ domakinstvo, with the subtitle Semeen zhurnal ('Family Journal'), was first published in May 1897. It appeared fortnightly (on the first and the fifteenth of the month) and was printed in Sofia for nine years until 1906. The director, publisher and conceptual inspirer of that project, innovative for its time and regional positioning, was the prominent metropolitan woman, fashion designer and teacher Elena Usheva (1872-1941). Launching a new role model for her contemporaries, she actively assisted, through her personal life experience and publications, the emancipation and cultural modernisation of Bulgarian women from the end of the nineteenth century.

Orphaned at eleven and widowed at sixteen, Usheva was a self-made success story. She completed her primary education in Stara Zagora, where she impressed her teachers with her intellect and skills demonstrated in her handicraft classes. The teacher and writer Atanas Iliev, a Prefect in the Stara Zagora county at that time, offered her support. He convinced the mayor and town councillors to provide her with a scholarship to study at the School for Applied Arts in Brussels. Having graduated with distinction and a personal recommendation from the school director, Usheva returned to Bulgaria and started working as a teacher in the town of Gabrovo. In 1892 she decided to participate in the First Bulgarian Trade Fair in Plovdiv with her examination work, a fashionable silk blouse exquisitely decorated with Bulgarian popular folk embroidery. The original blouse impressed the young Queen Maria-Louisa, ${ }^{4}$ who had just arrived in the country: she bought the blouse and appeared dressed in it at the first palace ball in the capital Sofia. That personal recognition motivated Usheva to move to Sofia and start working there, while her professional reputation began to spread rapidly (Koicheva, 2012).

\footnotetext{
${ }^{4}$ Maria-Louisa was the wife of the Bulgarian ruler at that time, King Ferdinand I.
} 
Supported by minister of the education Ivan Shishmanov, who had spotted her talent at a local exhibition, Usheva founded the first Manual Courses on Bulgarian Embroidery in Sofia, where nearly 60 girls were trained from the beginning (Koicheva, 2012; Slivopolska, 1939; Stoykov, 1999). The courses became the basis of the Maria Luisa professional school for girls, founded by the philanthropic women's association Maika (Mother) in 1893. Usheva also edited several women's magazines, among them Moda i domakinstvo (1897-1906), Rakodelno spisanie ('Handicraft Magazine'; 1905), and Domakinsko ilystrovano spisanie ('Household Illustrated Magazine'; 1907 -1908).

Perhaps the overall portrait of the new 'Bulgarian woman', as personified and visualised by Usheva and, in general, by the household periodicals in Bulgaria after 1878, that of a professionally educated person, with up-todate knowledge in various aspects of life, and an equal partner in her family, was demonstrated for the first time by building the image of Moda i domakinstvo's 'implied reader' (Iser, 1974). Apart from the 'implied' category, Iser's classification includes 'ideal' and 'real' readers as well. While we can imagine the profile of 'implied' or even 'ideal' readers of the periodical, at this stage of research on the history of readership in Bulgaria it is impossible to build a comprehensive picture of the real readers in late-nineteenth and early-twentieth-century Bulgaria.

From its very beginning the goals of Moda i domakinstvo were clearly articulated by its editor: to provide Bulgarian women with a modern magazine able to satisfy their interests in the field of fashion; to publish useful tips for everyday life; and last, but not least, to enrich the readers' spiritual world by acquainting them with Bulgarian and world literature and culture. The editor emphasised that the journal was useful for every family and every home, both for its practical orientation and for its educational materials, the latter being especially interesting for 'women teachers and schoolgirls' (Moda i domakinstvo, 1897: 16). The social groups that Moda i domakinstvo and Bulgarian household periodicals in general recognised as their readership were educated urban women and housewives - the women with the necessary intellectual and time resources for periodical press consumption. In addition to satisfying their spiritual needs and curiosity about fashion, reading household journals was a way for many of them to expand their household knowledge, since the patriarchal family, typical for rural settlements, was no longer the only context in which women's experiences were formed. ${ }^{5}$ The growing network of girls' schools also contributed to those processes of generational separation: it introduced girls to a new social environment, placing them under the influence of authorities different from their families; it also formed the largest professional group of working women in Bulgaria, that of the teachers, where the separation from home and parents was even sharper.

Moda i domakinstvo was divided into four sections - 'Scientific and Literary'; 'Fashion'; 'Household' and 'Various' (covering news, topics and issues not discussed by the other sections). During the first two years of publication, its contents privileged the Fashion section. Located on the first pages, it provided materials on topics ranging from examples of world fashion (mostly French) to drawings of models (of clothes, hairstyles, handicraft patterns), accompanied by instructions regarding their implementation, decoration, proper fabric, colour, etc. After the establishment of the Bulgarian nation state (but with its roots in Ottoman times, within the Bulgarian national revival period), Western fashion was recognised as one of the first channels for the cultural modernisation and Europeanisation of Bulgarian society, adopted along with contemporary Western institutions and laws, ideologies and intellectual, artistic and other tendencies. ${ }^{6}$ In particular, the seasonal character of clothing, a point on which the magazine insisted across various issues, was among the visual signs of the changing Bulgarian culture: it came to displace one of the traditional functions of clothes, to serve as a marker of ethnic and religious origin (as with the role of folk costume during the Bulgarian national revival).

The 'Household' section was the next to follow the idea of modern organisation of urban everyday life, viewed in its material and spiritual dimensions. It included various articles on: the rational management of the household (for example, guides to household bookkeeping and planning); domestic and personal hygiene, recognised as significant, but underemphasised in everyday life; tips for keeping a good appearance; and children's education and psychology. It was not only the modernising ethos that lay behind those publications, but also the efforts for the validation of women's work and duties in the house as a specific legitimate occupation. As Marina Vujnović notes in another context, this not only opened a public discussion related to women's life within the home and day-today activities, creating a new visibility for urban housewives in the public sphere, but also 'gave women the right to demand a part of their husbands' income for the personal everyday needs' (Vujnović, 2008: 197; Vujnović 2009).

As the work of many historians has already demonstrated, among them British historian Eric Hobsbawm, this demand was not surprising within the 'masculinized economies' of 'the family wage', typical for the transition to modernity. In such economies, a man's salary should ideally be fixed in a way not to require any other contribution to a wage, sufficient to keep all family members (Hobsbawm, 1989: 34-55). It is not surprising then that throughout

\footnotetext{
${ }^{5}$ As shown by demographer Robert McIntyre, at the end of the nineteenth and the beginning of the twentieth century, in the Bulgarian cities and even in villages, young couples lived separately from their parents in small nuclear families, typical for modern times (McIntyre, 1980).

${ }^{6}$ Interestingly enough, one of the first Bulgarian comedies, characteristically entitled 'Krivorazbranata tsivilizatsia' ('The wrongly understood civilisation'), criticised the Bulgarian upside-down notion of 'Europeanness', where 'the vogue is substituted for the civilization' (Daskalov, 1997: 141-180).
} 
the late nineteenth and early twentieth century, feminists worldwide argued for including women's unpaid household work in the national income, in an attempt to validate the private sphere, to which women had been relegated by patriarchal ideology.

The numerous culinary recipes published in each issue, also located in the 'Household' section, were another sign of cultural modernisation, since nutrition is a cultural practice related to the processes of communication and socialisation, a mark of the 'modern' status of a given society. By promoting new recipes among its female readership, the magazine broke into Bulgarian culinary traditions, popularised the achievements of modernity, sought to cultivate new habits among Bulgarian households, 'introducing new products, dishes and spices, modern methods of food preparation, new standards of serving and eating, unfamiliar understanding of the purpose of food' (Nazurska, 2006: 12). The history of family nutrition implicitly registered by periodicals like Moda i domakinstvo has been thoroughly studied by historian Raina Gavrilova. Placed within a broad socio-historical and cultural context, it has been analysed in a close connection with other life parameters, such as urbanisation and the specific characteristics of the Bulgarian urban environment from the late nineteenth and the early twentieth century. Changes in nutrition, an everyday practice, saturated with cultural meanings and referring to power relations, connections and emotions among family members, have been thought of as a reflection of the modernisation dynamics of Bulgarian society, a meeting point of macrohistory and microhistory (Gavrilova, 2016).

A special category included in the same section and a growing part of the journal was devoted to the need for women's professional education. According to various statistics, a gradual rise of women's activities in the sphere of paid labour was registered after the establishment of the Bulgarian nation state, in spite of the numerous legislative measures and social beliefs that inhibited women's attempts to show that they could fully realise themselves beyond the private sphere. After 1878 women continued to work in the teaching profession, the first mass intellectual occupation, to which they had gained access already within the Ottoman Empire during the period of the (so-called) national revival. Women also managed to break through as clerks in post offices, the telegraph and telephone stations. However, it was not until the beginning of the twentieth century that women in Bulgaria became visible in prestigious, male-dominated professions and built careers as journalists and editors, authors of poetry and prose, doctors, artists, and architects (Daskalova, 2012: 355-6).

The materials on women's professional education published in Moda $i$ domakinstvo reflected the ambivalent understanding of the male liberal elites of the Bulgarian nation state about modernity: women's social role was considered important for the national economic development, but their loyalty to traditional motherhood and cultivation of traditional feminine virtues were thought to be fundamental in protecting the Bulgarian nation from subversive foreign ideas and practices. The voices of the opponents of women's paid work outside the home, who insisted that the two genders should occupy separate physical spaces and that women's place was in the household, under the protection and control of men, were still strong in the early twentieth century (Daskalova, 2012: 346). Hence, the oscillation of the magazine between essentialist texts, falling within the traditional framework of supporting women's fulfilment as wives, housewives and mothers (promoting skills and knowledge that could be applied in the private sphere), and articles that appeared to be a source of modernising and emancipating tendencies among the readers and their 'horizon of expectations' (Iser, 1974). By giving examples of women who could earn their living outside the home and prove themselves as professionals, the latter served as a stimulus for the subsequent development of Bulgarian women as autonomous individuals, visible figures in the public sphere, as well as more active participants in the social and political life of the country. Moda $i$ domakinstvo thus helped formulate the arguments of the raising (though still tiny) number of independent professional middle class women at the forefront of the organised feminist movement in the country at the beginning of the twentieth century, when the first big national feminist organisation, the Bulgarian Women's Union, was established in 1901.

A powerful source of such suggestions were the articles that drew parallels between the situation of women in Bulgaria and that of their contemporaries in other European countries. The article 'Women's Associations in Switzerland', for example, informed the readers about the variety of free-of-charge courses aiding women's selfimprovement that were initiated by the women's organisations in the country, such as language training, and courses in bookkeeping, stenography and typing. It also drew attention to the regularly organised public talks on the situation of women in Switzerland and around the world. An important focus of the publication was the observation that, while the majority of women's associations in the country were pursuing practical goals, they contributed, through their work and efforts, to the success of the local women's movement: they raised awareness of the need to expand the field of women's activities and supported referenda on freedoms that were previously denied to women (in the Canton of Geneva, for example, the adoption of laws to restrict the husbands' authority and the recognition of women workers' rights over their work). The article also focused on the fact that reforms in women's education had been undertaken in a number of Swiss cantons as recognition of the principle of mixed education of girls and boys. Hence, the growing number of women trained in Swiss universities, the wider admission of women to positions of university professors and, as a result of educational changes, the recently enacted law to allow women to practice in the legal profession in Zurich (Moda i domakinstvo, 1904: 8-12). By 
contrast, in Bulgaria, women with an education in law were not allowed to practice as lawyers until 1945, although the Bulgarian Women's Union and other women's organisations, such as the Association of Bulgarian Women with University Education, fought several decades for this professional right (Daskalova, 2017: 198-216).

News on women pioneers in diverse educational and professional areas (going beyond the traditionally considered female 'predispositions') was published under the rubric 'Women's News'. This section informed readers of women chemists (trained in courses at the laboratory of the Higher Agricultural School in Berlin), women carpenters (leading factories in Copenhagen), pharmacists (trained in Germany), women with PhDs in philosophy (who had obtained their diplomas at Vienna University), among others. Such materials suggested that women could realise themselves as respectable members of society in various professional spheres, while successfully balancing their private and public roles (Moda i domakinstvo, 1902: 3). Usheva's strong appeal to the parents of girls to educate their daughters and give them 'broad and solid knowledge' was in tune with contemporary European and Bulgarian feminist ideas, which prioritised education as a primary source for women's emancipation and personal development.

Bulgarian women's intellectual development and the extension of women's cultural horizons and knowledge were also recognised as tasks through the third, 'Scientific and Literary', section of the magazine. This was responsible for the promotion of popular science articles, as well as for the good selection of fiction and poetry (poems, aphorisms, stories, novels, reviews). The section offered a varied sample of Bulgarian and world literature: works by well-known Bulgarian (mostly male) writers, such as Anton Strashimirov and Kiril Hristov. The only female author who appeared on the pages of this periodical was Anna Karima, who was also one of the first leaders of the Bulgarian Women's Union and editor of its organ, the (already mentioned) newspaper Zhenski glas. The predominance of works by male authors on the pages of periodicals, including household ones, was the norm in the Bulgarian cultural and social context from the last quarter of the nineteenth to the first decades of the twentieth century. Women's literature was steadily marginalised by critics, thought of as secondary to men's, and perceived not so much through its artistic parameters as through its gender bias. Even when, in the interwar period, with the development of education and the strengthening of emancipatory tendencies in Bulgarian society, more and more women of letters demanded their right to a place in the public space and intellectual life of the country, demonstrating both productivity and innovation in terms of themes and genres, only a few of them were included in the Bulgarian literary canon (Kirova, 2009).

Moda i domakinstvo published translations from foreign authors like Anton P. Chekhov, Guy de Maupassant, Mark Twain, Alphonse Daudet, Matilda Serrao, August Strindberg, some of whose female protagonists are rebellious, unconventional women. The goal of cultivating reading habits and developing a more sophisticated taste among the female readership, by publishing selected literary works capable of creating spiritual needs and provoking critical thinking, was a cultural and educational mission steadily pursued by the household periodical press in modern Bulgaria, which would gain particular intensity during the interwar period, when these types of periodicals were booming.

A translated article by L. Gizitzka on 'The new woman in literature' was particularly interesting and indicative of the overall conceptual orientation of the magazine. The literary material to which the text referred (Sarah Grant's Heavenly Twins and Pierre Nansen's Divine Peace, the works of August Strindberg, Laura Malhorn, Hermann Sudermann and Gerhart Hauptmann) and the female literary protagonists cited as examples, in particular, were used to build the collective image of the self-confident 'new free woman', the one visualised by the magazine as a role model for the modern Bulgarian woman. The conclusion of the article, a kind of a programme for Moda $i$ domakinstvo, stated that:

the new free woman will bravely go alongside her beloved man, educate the leaders of the people, the bearers of the future - the new people (Gizitzka, 1901: 3-5).

It would not be an exaggeration to say that, with the general aim of modernisation and emancipation of Bulgarian society in general and Bulgarian women in particular, such a message (and the conceptual profile of the magazine as a whole - a true pioneer among the household periodicals in early modern Bulgaria) was very close to the 'relational' feminism as defined in the beginning.

\section{CONCLUSION}

In this article, using the case of Moda $i$ domakinstvo, I argued that the role of Bulgarian household periodicals (the newspapers and magazines focusing on the home and its maintenance, family relationships and women with their problems and needs) was not limited to an attempt at building an exemplary reconstruction of the women's world in the variety of its aesthetic and moral dimensions. Following the ambition to modernise their female readership by discussing a wide range of themes, and driven by strong educational and emancipatory impulses, 
those journals testified to the accelerating process of involving Bulgarian society in modern emancipatory ideas, including those of gender equality and the need to overcome conservative (outdated) power structures and traditional gender hierarchies. The relevance of their approach to Bulgarian readers is confirmed by the boom in publications with a household profile in the interwar period. If, before the War, the only influential magazine of that kind, leaving a lasting imprint in the Bulgarian media and cultural environment was Moda $i$ domakinstvo, the time that followed (until 1944) registered a growing number of women's magazines with diverse content, accompanied by many advertisements. Unlike most narrowly profiled and political publications, the Bulgarian household press enjoyed a long existence, testifying to its ability to more and more sustainably monopolise readers' tastes. Apart from the wide range of topics covered, a possible explanation for this longevity could be found in the resilience of patriarchal ideas and the understanding of women's roles, responsibilities and societal status coded by patriarchy. This set of beliefs was long-lived in the Bulgarian context, despite the will to modernise demonstrated nationwide.

On the other hand, by incorporating relational feminist arguments into their rhetoric (according to Offen's definition) household periodicals tried to correspond both to the specifics of their Bulgarian (and Balkan) social, economic and cultural reality, and to emancipatory tendencies on a global scale. They actually reflected the intellectual entanglements between the Bulgarian and other European contexts (such as the French, the British, the Russian and the Greek) where the 'woman question' and its resolution was recognised as a key part of the projects for national development and modernisation. As the women's press at the turn of the twentieth century functioned as one of the key contributors to the emerging Bulgarian public space, similarly to its role in other European societies, it could be productively studied by applying a relational and reflexive approach, or as demonstrated by Francisca De Haan in her research on women's movements and feminisms, within the paradigm of 'entangled history' (De Haan, 2017). The current focus on the magazine Moda i domakinstvo was a selective attempt to analyse the contribution of Bulgarian household periodicals to women's emancipation and cultural modernisation in a certain historical period. Despite its regional positioning, the article addresses the broader topic of the entanglements of feminist/emancipatory ideas spreading through the women's periodical press, which deserves to be the subject of a large-scale comparative international study.

\section{REFERENCES}

Ardis, A. and Collier, P. (eds) (2008). Transatlantic Print Culture, 1880-1940. Emerging media, emerging modemisms. Hampshire, New York: Palgrave Macmillan.

Ardis, A. and Lewis, L. W. (eds) (2003). Women's Experience of Modernity, 1875-1945. Baltimore and London: Johns Hopkins University Press, 2003.

Barać, S. (2015). Feministička kontrajavnost: Žanr ženskog portreta u srpskoj periodici 1920-1941. [The feminist counterpublic: A genre of woman's portrait in the Serbian periodical press from 1920 to 1941]. Belgrade: Institut za knjizevnost i umetnost.

Brevik-Zender, H. (2014). Interstitial narratives: Rethinking feminine spaces of modernity in nineteenth-century French fashion plates. Nineteenth-Century Contexts, 36(2), 91-123.

Bucur, M. (2017). Gendering Modernism: A historical reappraisal of the canon. London, Oxford, New York, New Delhi, Sydney: Bloomsbury Academic.

Bucur, M. (2018). The Century of Women. How women have transformed the world since 1900. Lanham, Boulder, New York, London: Rowman \& Littlefield.

Dalakoura, K. (2012). Challenging education in the Ottoman Greek female journals (1845-1907): A declining feminist discourse. Knjizenstvo, 2(2). Available at: http://knjizenstvo.rs/print.php?text=49. (Accessed 15 May 2020).

Daskalov, R. (1997). Ideas about and reaction to modernization in the Balkans, East European Quarterly, 31(2), 141180.

Daskalov, R. (2015). Bulgarskoto obshtestvo 1878-1939 [Bulgarian society 1878-1939], 2. Sofia: Gutenberg.

Daskalova, K. (1998). Bulgarskite zheni v socialni dvizhenia, zakoni i diskursi [Bulgarian women in social movements, laws and discourses] (1840-1940), in Ot siankata na istoriata: Zhenite v bulgarskoto obshtestvo i kultuara (1840-1940) [From the shadows of history: Women in Bulgarian society and culture (1840-1940)] (pp. 11-41). Sofia: Dom na naukite za choveka i obshtestvoto.

Daskalova, K. (2001). Zhenskata identichnost: normi, predstavi, obrazi v bulgarskata kultura ot XIX - nachaloto na XX vek [Female identity: Norms, concepts, images in Bulgarian culture from the XIX ${ }^{\text {th }}$ century to the beginning of the XX ${ }^{\text {th }}$ century], in Balkanski identichnosti [Balkan identities], II, (pp. 157-229). Sofia: Open Society Foundation.

Daskalova, K. (2012). Zheni, pol i modernizacia v Bulgaria, 1878-1944 [Women, gender, and modernization in Bulgaria, 1878-1944]. Sofia: St. Kliment Ohridski.

(C) 2020 by Author/s 
Daskalova, K. (2016). Zhenskii sviat i zhenskata emancipacia v kontexta na bulgarskata modernizacia (1893-1898) [Women's World and women's emancipation in the context of Bulgarian modernization (1893-1898)], in Nachalata na bulgarskata modernist. Revoljucioni idei i vsekidnevni praktiki [The beginnings of Bulgarian modernity. Revolutionary ideas and everyday practices], XXI, (pp. 9-23). Rousse: TS Group.

Daskalova, K. (2017). Bulgarian Women with Education in Law during the First Half of the Twentieth Century, in S. Kimble and M. Roewekamp (eds), New Perspectives on European Women's Legal History (pp. 198-216). New York: Routledge.

De Beauvoir, S. (2010). The Second Sex. New York: Vintage Books.

De Haan, F. (2017). Writing Inter/Transnational History: The Case of Women's Movements and Feminisms, in B. Haider-Wilson, W. D. Godsey, and W. Mueller (eds), Internationale Geschichte in Theorie und Praxis / International History in Theory and Practice (pp. 501-536). Vienna: Austrian Academy of Sciences.

Delap, L. (2007). The Feminist Avant-Garde: Transatlantic encounters of the early twentieth century. Cambridge: Cambridge University Press.

Dojčinović, B and Kolarić, A. (eds) (2018). Feminističk štampa u Srbiji: teorija, aktivizam i umetničke prakse u 1990-im $i$ 2000-im [The feminist press in Serbia: theory, activism and art practices in the 1990s and 2000s]. Belgrade: Filosofski Fakultet u Univerziteta Beogradu.

Dorosieva, L. (1995). Moda i domakinstvo (1897-1906) [Fashion and Household (1897-1906)], in Periodika $i$ literatura [Periodicals and literature], 2, 1893-1901 (pp. 291-294). Sofia: Izdatelstvo na bulgarskata academia na naukite.

Felsi, R. (1995). The Gender of Modemity. Cambridge, MA, and London: Harvard University Press.

Gavrilova, R. (2016). Semeinata scena: antropologicheska istoria na semeinoto hranene v Bulgaria v modernata epoha [The Family Scene: anthropological history of the family feeding in Bulgaria during the modern times]. Sofia: St. Kliment Ohridski.

Georgiev, G. (1970). Osvobozhdenieto i etnokulturnoto razvitie na bulgarskia narod 1877-1900 [The liberation and ethnocultural development of the Bulgarian people 1877-1900]. Sofia: Bulgarian Academy of Sciences.

Gigova, I. (2008). The feminization of Bulgarian literature and the Club of Bulgarian Women Writers. Aspasia. The International Yearbook of Central, Eastern, and Southeastern European Women's and Gender History, 2(1), 91-119.

Gizitzka, L. (1901). Novata zhena v literaturata [The new woman in literature], Moda i domakinstvo [Fashion and Household], I(5-6), 3-5.

Hobsbawm, E. (1989). The Age of Empire (1875-1914). New York: Vintage Books.

Iser, W. (1974). The Implied Reader: Patterns of communication in prose fiction from Bunyan to Beckett. Baltimore: Johns Hopkins University Press.

Ivanchev, D. (1978-1983). (ed) Bulgarski knigi. $1878-1944$ [Bulgarian books. 1878-1944], 1-6. Sofia: National Library SS. Cyril and Methodius.

Katsarov, K. (1970). 60 godini ₹biviana istoria [60 years living history]. Montreux: Promidrin.

Kirova, M. (2009). (ed). Neslucheniat kanon: Bulgarskite pisatelki ot Vuzrazhdaneto do Vtorata svetovna voina [The canon that did not happen: Bulgarian women writers from the national revival to World War II]. Sofia: Altera.

Kirova, M. (2013). (ed). Neslucheniat kanon: Bulgarskite pisatelki ot 1944 godina do nashi dni [The canon that did not happen: Bulgarian women writers from 1944 till now]. Sofia: Altera.

Koicheva, V. (2012). Elena Usheva - ime, pokrito sus zabrava [Elena Usheva - a Name covered with oblivion], in Starozagorski hroniki otpredi i sled Osvobozhdenieto [Stara Zagora chronicles before and after the Liberation] (pp. 125-128). Stara Zagora: Lagen.

Kolarić, A. (2017). Rod, modernost i emancipacija. Uredničke politike u časopisima 'Žena' (1911-1914) i 'The Freewoman' (1911-1912) [Gender, modernity and emancipation: Policies of editing in the journals The Woman (1911-1914) and The Freewoman (1911-1912)]. Belgrade: Fabrika knjiga.

Korte, B. (2015). Between fashion and feminism: History in mid-Victorian women's magazines, English Studies, 96(4), 424-443.

Kourtasheva, B. (2012). Antologii i kanon: antologiini modeli na bulgarskata literature [Anthologies and canon: anthology models of Bulgarian literature]. Sofia: Prosveta.

McIntyre, R. (1980). The Bulgarian anomaly: Demographic transition and current fertility, Southeastern Europe, 7(2), $147-170$.

Malinova, L. (1995). Grazhdanka (1911-1912) [Woman Citizen (1911-1912)], in Periodika i literatura PPeriodicals and literature], 4, 1911-1917 (pp. 120-125). Sofia: Akademichno izdatelstvo Prof. Marin Drinov.

Malinova, L. (1999). Bulgarskite poetesi meşbdu dvete svetovni voini [Bulgarian poetesses of the interwar period]. Sofia: Vanyo Nedkov.

Marek, J. (1995). Women Editing Modernism: 'Little' magazines \& literary bistory. Lexington, KY: University of Kentucky Press. 
Moda i domakinstvo (1904). Zhenskite asociacii v Shveicaria [Women's associations in Switzerland], Moda $i$ domakinstvo [Fashion and Household], II(14), 8-12.

Morrisson, M. (2001). The Public Face of Modernism: Little magarines, audiences, and reception, 1905-1920. Madison: University of Wisconsin Press.

Nazurska, G. (2006). Gotvarskite knigi kato stimul za kulturna modernizacia: ot Slaveykov do Cholcheva [Cookbooks as an incentive for cultural modernization: From Slaveikov to Cholcheva] (1870 - 1944), Biblioteki, chetene, komunikacii [Libraries, reading, communication], VII, 12.

Nazurska, G. (2007). Kulturnata recepcia na zhenskia periodichen pechat (30-60-te godini na XX v.): Opit za reconstrukcia po danni ot chasten arhiv [Cultural reception of women's periodicals (1930s and 1960s): An attempt at reconstruction via data from a private archive], Izdatel [Publisher], IX(3-4), 11-20.

Nikolchina, M. (2002). Rodena ot glavata: Fabuli i sjuzheti v zhenskata literaturna istoria [Born from the head: Fables and stories in women's literary history]. Sofia: Sema RSH.

Offen, K. (2000). European Feminisms, 1700-1950; a political history. Stanford: Stanford University Press.

Sanz, A., Scott, F. and Van Dijk, S. (eds) (1997). Women Telling Nations (Women Writers in History) (p. 18). Amsterdam, New York: Rodopi.

Scholes, R. and Wulfman, C. (2010). Modernism in the Magazines: An introduction. New Haven: Yale University Press.

Scott, B. K. (ed) (2007). Gender in Modernism. New geographies, complex intersections. Urbana and Chicago: University of Illinois Press.

Slivopolska, N. (1939). Maika na profesionalnoto obrazovanie u nas [Mother of professional education in Bulgaria], Zhena i dom [Woman and Home], 17, 29-30.

Stoykov, L. (1999). Bulgarskata moda prez XX v. Shtrihi kum dinamikata na vkusa i elegantnostta [Bulgarian fashion in the 20th century. Strokes to the dynamics of taste and elegance], Almanah na bulgarskata moda 2000 [Almanac of Bulgarian fashion 2000]. (pp. 10-11). Sofia: Ot igla do konec.

Van Remoortel, M. (2017). Women Editors and the Rise of the Illustrated Fashion Press in the Nineteenth Century, Nineteenth-Century Contexts, 39(4), 269-295.

Vujnović., M. (2008). Forging the Bubikopf Nation: A feminist political-economic analysis of Zenski list, interwar Croatia's women's magazine, for the construction of an alternative vision of modernity (Dissertation). University of Iowa. Available at: https://ir.uiowa.edu/cgi/viewcontent.cgi?article=1217\&context=etd\&unstamped=1 (Accessed 15 April 2020).

Vujnović., M. (2009). Forging the Bubikopf Nation. Journalism, Gender, and Modernity in Interwar Yugoslavia. New York: Peter Lang Publishing Inc.

Citation: Mitkova, V. (2020). Household Periodicals, Modernisation and Women's Emancipation in Bulgaria (1890s to WWI). Feminist Encounters: A Journal of Critical Studies in Culture and Politics, 4(2), 24. https://doi.org/10.20897/femenc/8512

Copyright (C) 2020 by Author/s and Licensed by Lectito BV, Netherlands. This is an open access article distributed under the Creative Commons Attribution License which permits unrestricted use, distribution, and reproduction in any medium, provided the original work is properly cited. 